\title{
PENGEMBANGAN PETA PRAKIRAAN DAERAH PENANGKAPAN IKAN
}

\author{
Bambang Sukresno ${ }^{a, *}$, Denny Wijaya Kusuma ${ }^{a}$

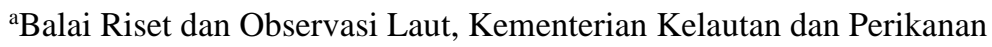 \\ *Koresponden Penulis : bambang_sukresno@yahoo.com
}

\begin{abstract}
Abstrak
Riset pengembangan Peta Prakiraan Daerah Penangkapan Ikan (PPDPI) telah berjalan sejak tahun 2000 yang dilakukan oleh Balai Riset dan Observasi Laut (BROL) - Kementerian Kelautan dan Perikanan. PPDPI merupakan salah satu upaya pemerintah dalam mendukung pengelolaan sumberdaya perikanan yang bertanggungjawab dan berkelanjutan. Dalam pengembanganya, PPDPI disusun berdasarkan pada data satelit yang mampu menyajikan parameter oseanografis dengan resolusi spatial yang tinggi serta resolusi temporal harian. Beberapa parameter yang digunakan untuk analisis antara lain suhu permukaan laut, konsentrasi klorofil-a, tinggi permukaan laut, sub surface temperature dan dilengkapi dengan informasi kecepatan angin serta tinggi gelombang. Terdapat beberapa jenis peta yang dihasilkan, antara lain PPDPI nasional, PPDPI pelabuhan dan PPDPI spesies khusus. Metode pembuatan PPDPI pada awalnya menggunakan proses yang sederhana berupa tumpang susun (overlay) beberapa data satelit. Kemudian mengalami perkembangan dengan dilakukanya image analysis identifikasi fenomena front. Pada penyusunan PPDPI untuk spesies khusus dilakukan dengan analisis Generalized Aditif Model (GAM), sedangkan PPDPI ikan tuna disusun berdasarkan analisis Empirical Cumulative Distribution Function. Berdasarkan pada validasi menggunakan data penangkapan ikan dapat diketahui bahwa akurasi PPDPI memberikan informasi dengan akurasi yang cukup tinggi, bahkan mencapai 87,2\%. Pendistribusian informasi PPDPI kepada pengguna baik nelayan maupun pemangku kepentingan dan pengambil kebijakan dilakukan dengan berbagai media sehingga dapat di akses secara mudah, cepat dan mampu menjangkau ke seluruh wilayah Indonesia.
\end{abstract}

Kata kunci : Peta, Perikanan, data satelit, Suhu permukaan laut, Klorofil-a

\begin{abstract}
The Institute for Marine Research and Observation (IMRO) - Ministry of Marine Affairs and Fisheries has initiated research on the Potential Fishing Ground (PFG) since 2000. PFG is one of the government's intentions to reinforce responsible and sustainable fisheries resources management. In its development, we compiled PFG based on satellite data which can provide oceanographic variables with high spatio-temporal resolution. The data employed for the assessment include sea surface temperature, chlorophyll-a concentration, sea level, subsurface temperature, and completed by information of wind speed and wave height. There are several types of maps presented, including PFG for nationwide coverage, PFG of fishing port-based, and PFG of species-based. The initial design applied to develop the PFG was a direct process of superimposing several satellite data. The further method of PFG analysis was single image edge detection to identify the sea surface temperature front. The other method performed to produce PFG of species based was the Generalized Additive Model (GAM). Furthermore, PFG for tuna was prepared based on the analysis of the Empirical Cumulative Distribution Function. Based on the validation using the fishing logbook, we can verify that the PFG provides information with high accuracy of $87.2 \%$. The distribution of PFG information to users including fishermen, stakeholders and policy makers is carried out with various platforms so that we can access it throughout the Indonesian area.
\end{abstract}

Keywords: Map, Fishery, satellite data, Sea Surface Temperature, Chlorophyll-a

\section{PENDAHULUAN}

\begin{tabular}{l} 
Pembangunan perikanan $\begin{array}{r}\text { Indonesia } \\
\text { kelestarian }\end{array}$ \\
kedepan harus memperhatikan and hal ini diperlukan agar \\
sumberdaya alam, he \\
\hline Article history: \\
Diterima / Received 25-05-2021 \\
Disetujui / Accepted 31-07-2021 \\
Diterbitkan / Published 31-07-2021
\end{tabular}

sumberdaya perikanan dapat dinikmati oleh generasi penerusbangsa ini. Salah satu kunci dalam melakukan pelestarian sumberdaya perikanan disamping konservasi adalah sistem penangkapan yang bertanggung-jawab. Kata (C)2021 at http://jfmr.ub.ac.id 
bertanggung-jawab disini dapat diartikan sebagai sebuah sistem penangkapan yang memperhatikan budaya dan dan kearifan lokal seperti halnya kalender penangkapan ikan, musim ikan dan lain sebagainya [1].

Kearifan lokal ini di masa sekarang dapat dipadukan dengan teknologi modern, yaitu dengan menggunakan data satelit yang dituangkan dalam bentuk sebuah peta yang disebut Peta Prakiraan Daerah Penangkapan Ikan (PPDPI). Peta tersebut memberikan informasi mengenai daerah potensial untuk penangkapan ikan. Informasi ini akan meningkatkan kepastian hasil tangkapan serta efisiensi waktu yang diperlukan. Nelayan memerlukan waktu yang cukup lama untuk mencari lokasi yang dianggap potensial untuk penangkapan. Dengan adanya informasi daerah potensial penangkapan ikan maka nelayan bisa langsung menuju lokasi yang sudah diinformasikan tersebut, sehingga bisa lebih efisien waktu dan bahan bakar untuk kapal [2]. Peta PPDPI disusun oleh Balai Riset dan Observasi Laut (BROL), Kementerian Kelautan dan Perikanan [3]. Sejak tahun 2000, Badan Riset Kelautan dan Perikanan (BRKP), Departemen Kelautan dan Perikanan (DKP) telah memberikan pelayanan jasa berupa informasi daerah penangkapan ikan dan telah disebarluaskan ke nelayan melalui koperasi nelayan di berbagai wilayah Indonesia [4].

PPDPI yang diproduksi oleh BROL terdiri atas beberapa jenis peta berdasarkan pada wilayah serta jenis ikannya. Jenis peta yang pertama adalah PPDPI nasional yang berisi informasi daerah potensial penangkapan ikan pelagis dengan cakupan seluruh wilayah Indonesia. Peta yang kedua adalah PPDPI berbasis pelabuhan, dimana peta tersebut diperuntukan bagi nelayan yang berada pada pelabuhan tertentu, sehingga informasi daerah potensial penangkapan ikan yang diberikan dapat dijangkau oleh armada kapal mereka [2]. Jenis peta selanjutnya adalah PPDPI khusus untuk spesies tertentu seperti tuna mata besar, tuna sirip kuning, tuna albakor dan tuna sirip biru [5], serta lemuru [6]. Penyusunan masing masing peta diatas memiliki metode yang berbeda-beda, karena masing-masing spesies memiliki korelasi yang spesifik terhadap faktor oseanografis.

\section{METODE}

Informasi PPDPI pada awalnya berupa peta anomali tinggi permukaan laut dan dibagi kedalam 3 (tiga) zona penangkapan [4]. Pada awal 2003 informasi ini telah ditingkatkan dengan menggabungkan hasil analisis dari 2 (dua) sumber data yakni satelit NOAA-AVHRR dan satelit TOPEX/POSEIDON. Sistem penyajian juga dikembangkan agar lebih detail dengan menyajikan 6 (enam) peta zona penangkapan. Dengan adanya peningkatan informasi ini diharapkan para nelayan dapat menangkap ikan di laut dengan efektif dan efisien [7].

Pada saat ini PPDPI disusun berdasarkan pada korelasi antara kelimpahan ikan khususnya ikan pelagis dengan kondisi lingkungannya. Oleh karena itu data perikanan merupakan salah satu inputan yang sangat penting. Data data tersebut akan dianalisis untuk mendapatkan pola persebaran serta kelimpahannya, yaitu dengan proses tumpang susun atau overlay dengan data oseanografis dari satelit [2]. Data perikanan didapatkan dari logbook kapal penangkapan baik data sekunder maupun dari hasil survey yang dilakukan oleh BROL.

Area yang sesuai untuk berkumpulnya ikan pada PPDPI didapatkan melalui analisis Suhu Permukaan Laut (SPL) yang kemudian dianalisis menjadi informasi front suhu. Adapun yang dimaksud dengan front suhu adalah pertemuan antara SPL dingin dan SPL hangat dengan selisih lebih dari SPL $0,5^{\circ} \mathrm{C}$. Analisis SPL juga memberikan informasi fenomena oseanografi yang disebut upwelling, yaitu proses naiknya masa air dari kedalaman laut menuju ke permukaan. Kejadian ini ditunjukkan dengan terdapatnya suhu dingin di sekitar suhu yang hangat. Komponen selanjutnya adalah konsentrasi klorofil-a. Variabel oseanografis ini adalah salah satu indicator berkumpulnya ikan di suatu perairan karena konsentrasi klorofil-a adalah kelas produsen dalam rantai makanan, sehingga jika di temukan konsentrasi klorofil-a yang tinggi maka proses rantai makanan akan terjadi. Di lokasi tersebut kemudian ikan-ikan 
sebagai konsumen tingkat 1 dan 2 berkumpul [8][9].

PPDPI nasional dan Pelabuhan disusun dengan mengunakan analisis terhadap faktor oseanografis seperti SPL, konsentrasi klorofil-a serta anomaly tinggi permukaan air laut. Data oseanografis tersebut didapatkan dari data satelit. Data SPL digunakan untuk menganalisis fenomena laut thermal front, yaitu bertemunya dua masa air laut dengan suhu yang berbeda. Fenomena laut Thermal front biasanya berasosiasi dengan arus yang relative kencang serta terdapat perbedaan tinggi permukaan air laut dibandingkan daerah sekitarnya [2]. Identifikasi thermal front menggunakan data satelit bisa dilakukan dengan mengaplikasikan metode Single Image Edge Detection (SIED) [10]. Thermal front berasosiasi erat dengan produktifitas suatu perairan, hal ini terjadi karena cenderung terjadi pada perairan dengan suhu yang relative lebih dingin serta kaya kandungan nutrien [11].

Proses penyusunan PPDPI nasional dan pelabuhan dapat dilihat pada Gambar.1. Dapat dijelaskan bahwa pembuatan PPDPI didasarkan informasi pada data satelit SPL dan konsentrasi klorofil-a yang merupakan indikator utama lokasi berkumpulnya ikan. Kedua informasi ini kemudian diformulasikan melalui algoritma hasil analisis korelasi kelimpahan terhadap faktor oseanografis. Selanjutnya ditambahkan juga informasi mengenai tinggi gelombang dan kecepatan angin. Selanjutnya informasi PPDPI tersebut disebarluaskan kepada pengguna yaitu nelayan serta pemangku kepentingan serta pengambil kebijakan terkait sumberdaya perikanan. Distribusi informasi PPDPI dilakukan menggunakan berbagai media baik media cetak maupun media elektronik.

Selain PPDPI nasional, saat ini BROL juga memproduksi PPDPI untuk spesies tertentu. Salah satu peta yang dibuat adalah peta PPDPI ikan lemuru Selat Bali. Hal ini didasarkan pada kondisi dimana selat Bali memiliki potensi perikanan tinggi khususnya ikan lemuru. Peta tersebut disusun berdasarkan pada variabilitas SPL dan Klor-a, namun metode yang diterapkan adalah Generalized Additif Model (GAM), dimana metode tersebut digunakan untuk memperhitungkan kelimpahan zooplankton

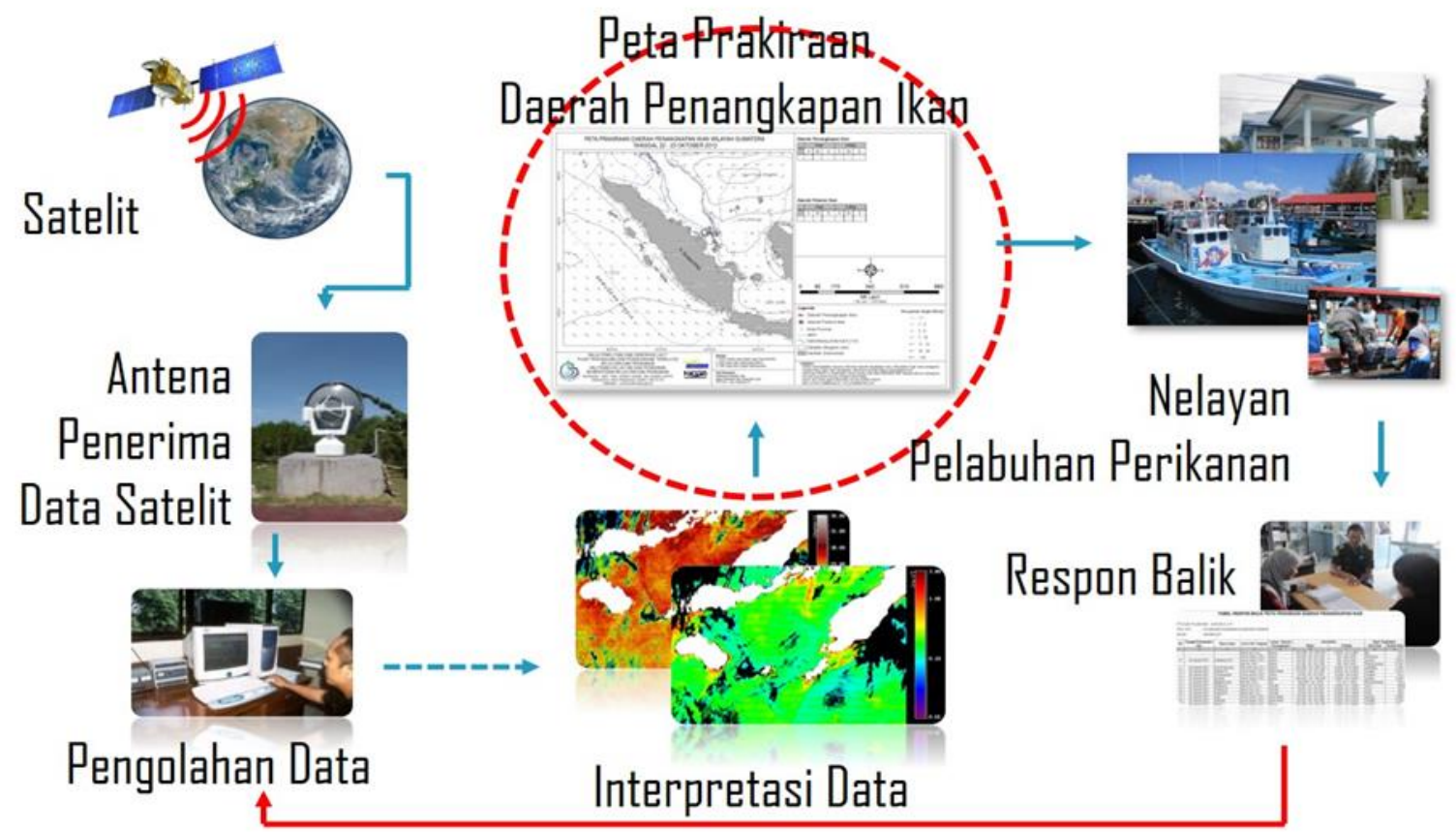

Gambar.1. Proses Pembuatan PPDPI Nasional 
sebagai indikator utama potensi ikan lemuru [6]. Disisi lain, potensi ikan lemuru juga dipengaruhi oleh kandungan nutrient pada air laut seperti nitrat, fosfat dan silica. Seiring dengan perubahan musim, jumlah tangkapan ikan lemuru juga mengalami fluktuasi. Hal ini terkait dengan adanya upwelling yang mempengaruhi kesuburan perairan di Selat Bali [12]. Kondisi oseanografis yang sama juga terjadi di Samudera Hindia selatan Pulau Jawa, dimana setiap tahun terjadi fluktuasi upwelling yang membawa masa air kaya nutrien ke permukaan laut. Dari hasil penelitian diketahui bahwa intenstasnya dipengaruhi oleh El Nino Southern Oscillation (ENSO) dan Indian Ocean Dipole Mode (IOD) [13].

Ikan tuna merupakan salah satu target utama dalam bidang perikanan tangkap, sehingga secara khusus dibuatlah PPDPI ikan tuna. Penyusunan PPDPI ikan tuna memiliki keunikan tersendiri dibandingkan dengan ikan pelagis lainya. Hal ini berkaitan dengan habitatnya yang berada pada kedalaman laut lebih dari 100 meter. Oleh karena itu data oseanografis yang digunakan untuk memprediksi daerah potensial penangkapan ikan tuna adalah suhu pada kedalaman tertentu atau sub surface temperature. Metode yang digunakan untuk menganalisis korelasi antara sub surface temperature dengan kelimpahan ikan tuna adalah empirical cumulative distribution function $(E C D F)$.
Dengan menggunakan metode tersebut maka daerah potensial penangkapan ikan tuna dapat di prediksi setiap hari [5].

Pembuatan PPDPI ikan tuna memerlukan proses lebih lama dan rumit jika dibandingkan dengan dengan PPDPI nasional dan pelabuhan, seperti yang disajikan pada gambar.2. Proses yang rumit ini disebabkan karena tingkat persisi yang tinggi dan banyaknya data insitu yang diperlukan untuk menyusun algoritma PPDPI.

Untuk melengkapi jenis PPDPI diatas, maka perlu dipertimbangkan adanya informasi untuk nelayan kecil yang beroperasi tidak jauh dari pesisir. Oleh karena itu kemudian dilakukan riset untuk mengetahui korelasi antara faktor lingkungan dengan kelimpahan ikan pelagis kecil di wilayah pesisir. Salah satu metode yang sesuai untuk menaganisis hal tersebut adalah Maximum Entropy Model. Dengan menggunakan metode tersebut maka dapat diketahui persen kontribusi masing masing variabel oseanografis yang kemudian digunakan sebagai dasar penyusunan PPDPI pesisir. Variabel yang digunakan sebagai inputan antara lain SPL, Klor-a, kedalaman laut atau batimetri, tinggi permukaan air laut, salinitas dan arus [14].

\section{HASIL DAN PEMBAHASAN}

\section{Resolusi PPDPI}

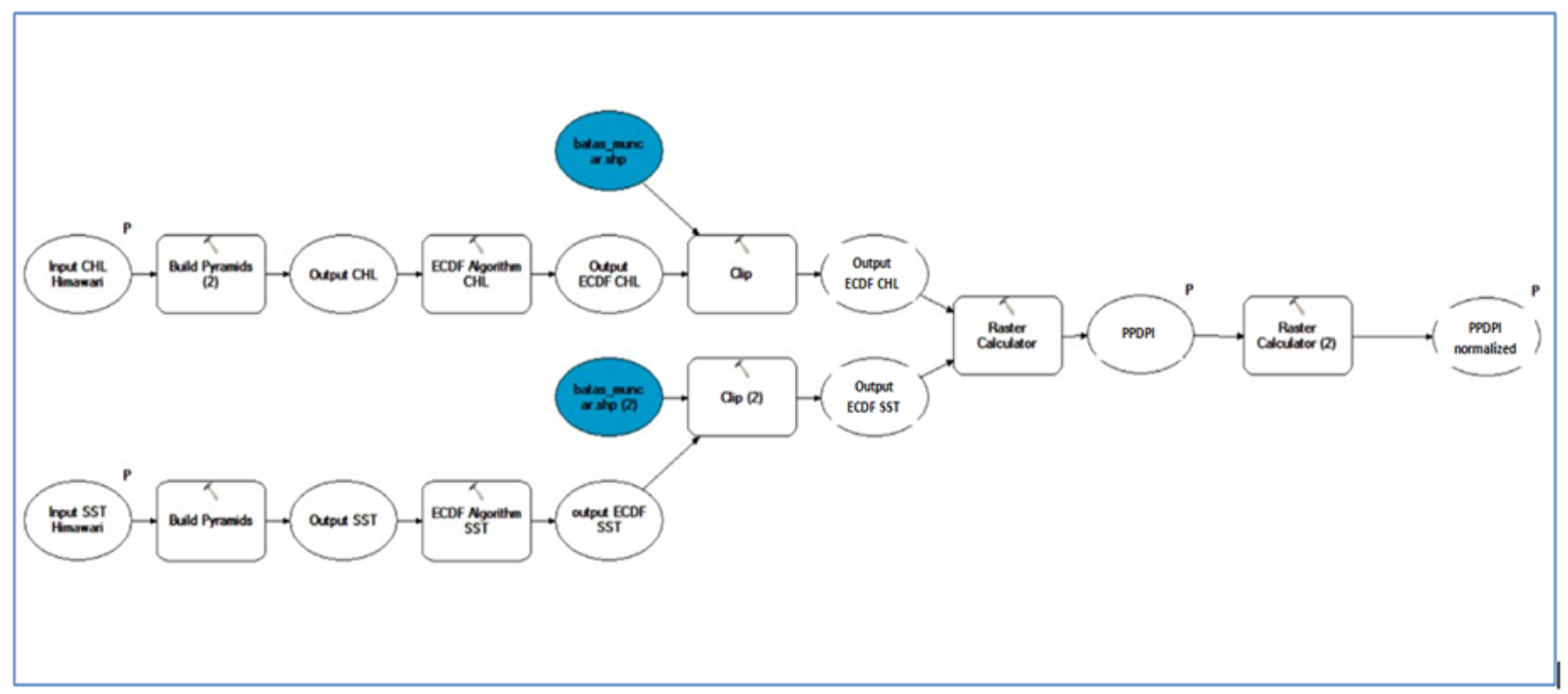

Gambar.2. Skema proses pembuatan PPDPI ikan tuna. 
Dengan menggunakan berbagai data satelit yang memiliki keunggulan dalam resolusi spasial maupun temporal maka berbagai informasi PPDPI telah bisa diproduksi oleh BROL dan didistribusikan kepada nelayan sebagai pengguna, kepada pemangku kepentingan serta pengambil kebijakan baik di pusat maupun di daerah. PPDPI nasional tersedia 3 kali dalam seminggu. PPDPI pelabuhan dan PPDPI lemuru diproduksi setiap hari. Sedangkan PPDPI ikan tuna selain diproduksi setiap hari juga dibuat prediksinya 7 hari kedepan sehingga memudahkan nelayan yang akan menuju lokasi penangkapan ikan.

\section{Akurasi PPDPI}

Selain keunggulan dalam resolusi spasial dan temporal ketika menyiapkan informasi daerah potensial penangkapan ikan, maka salah satu hal yang harus diperhatikan adalah akurasi dari peta tersebut. Berdasarkan pada riset yang telah dilakukan di laut jawa pada tahun 2015, dapat diketahui bahwa PPDPI memberikan informasi dengan akurasi yang cukup tinggi yang dibuktikan dengan densitas ikan sepanjang jalur survey yang telah dipediksi sebelumnya sebagai daerah potensial penangkapan ikan [15]. Selanjutnya pada survey validasi peta PPDPI di perairan Sulawesi Tengah menunjukan akurasi yang tinggi dimana semakin dekat dengan lokasi potensial penangkapan ikan, maka hasil penangkapan ikan yang didapatkan juga semakin banyak [16]. Apabila dilihat secara spatiotemporal persebaran wilayah yang memiliki potensi tinggi, maka akan terlihat suatu pola yang spesifik di tiap tiap Wilayah Pengelolaan Perikanan Republik Indonesia (WPP-RI). Dengan menggunakan teknologi data mining, telah dilakukan analisis penambangan data ruang dan waktu terhadap PPDPI nasional. Analisis tersebut meliputi space time cube yang digunakan untuk menyusun basis data multitemporal, dilanjutkan dengan analisis hotspot untuk mengetahui trend persebaran daerah potensial, dan kemudian dievaluasi dengan analisis MannKendall [17]. Akurasi peta PPDPI untuk ikan tuna mata besar yang disusun dengan menggunakan data dari ARGO-Float menunjukan akurasi yang tinggi yaitu dengan persentase kesesuaian sebesar $83,7 \%$. Akurasi tersebut bahkan lebih tinggi lagi jika data $s u b$ surface temperature yang digunakan adalah data dari Marine Copernicus (CMEMS) yang menunjukan akurasi sebesar 87,2\% [18]. Akurasi peta PPDPI tidak terlepas dari akurasi data satelit yang digunakan. Berbagai kendala yang ada harus ditindaklanjuti sehingga didapatkan data yang lebih baik. Permasalahan utama yang harus diupayakan penyelesainya antara lain adalah tutupan awan. Sebagaimana Indonesia berada pada wilayah tropis, maka secara umum memiliki tutupan awan yang sangat tinggi. Berbagai metode telah diteliti untuk mendapatkan data satelit yang relative bebas awan dengan resolusi spasial tinggi serta resolusi temporal harian. Beberapa metode yang dikembangkan antara lain gap filling yang dilakukan untuk mendapatkan data satelit bebas awan dengan cara menggabungkan data satelit multitemporal [19] Metode lain yang dikembangkan adalah rolling mosaik yang digunakan untuk mendapatkan data satelit bebas awan dengan menyusun mosaik atas data satelit secara timeseries [20]. Sedangkan metode interpolasi dilakukan untuk mendapatkan data satelit bebas awan dengan input berupa data satelit pada satu kali perekaman. Data yang tertutup awan akan diisi dengan mempertimbangkan data di sekitarnya [21]. Di sisi lain validasi data satelit terhadap kondisi sebenarnya di perairan Indonesia perlu dilakukan, sehingga dapat diketahui akurasi antara data satelit dengan data insitu [22].

\section{Distribusi PPDPI}

Pada periode tahun 2002 hingga 2014 PPDPI didistribusikan kepada pengguna melalui teknologi yang tersedia pada waktu itu antara lain

:

- Faksimil

Media ini adalah media yang paling banyak tersedia di seluruh wilayah Indonesia, namun memiliki kekurangan dalam proses pengirimanya yang harus dilakukan secara manual satu persatu sehingga memerlukan waktu yang relatif lama. 
- Email

Penggunaan email memberikan efisiensi waktu, namun kapasitas pengiriman datanya masih terbatas, serta belum seluruh wilayah Indonesia terjangkai internet.

- IVR (Interactive Voice Response)/FOD (Fax on Demand)

Sistem ini merupakan perangkat tambahan dari mesin faksimil yang juga menggunakan jaringan internet. Dengan system ini pengguna dapat menelpon ke pusat layanan di BROL dan akan mendapatkan informasi PPDPI yang diinginkan.

- Radio satelit Studio IFIC (Indonesia Fisheries Information Center))

Sistem ini merupakan perangkat siaran radio satelit komunikasi, sehingga dapat menjangkau seluruh wilayah perairan Indonesia.

Pada periode tahun 2005 hingga 2012 Sistem distribusi PPDPItelah berkembang pesat dengan tersedianya teknologi telepon genggam (Handphone). Sistem distribusi PPDPI dilakukan melalui berbagai media antara lain :

- website

Pada saat itu Departemen Kelautan dan Perikanan (DKP) sudah mempunyai website yaitu www.dkp.go.id, sehingga PPDPI dapat secara rutindiunggah di halaman tersebut. kemudian pada waktu berikutnya PPDPI juga dapat diakses melalui halaman www.brkp.dkp.go.id, serta www.bpol.litbang.kkp.go.id dan berkembang sampai saat ini.

- Melalui SMS

Dengan menggunakan sistem interaktif pengguna dapat memilih wilayah perairan yang diinginkan melalui pusat layanan SMS

- Melalui media sosial

Pada tahun 2012 PPDPI sudah didistribusikan melalui twitter dengan akun @PPDPI. Pada tahun 2018 hingga saat ini PPDPI memasuki perkembangan teknologi informasi yang jauh lebih baik dan tidak terbayangkan sebelumnya, mulai dariaplikasi whatsapp sampai dengan dimasukkan pada alat AIS (Automated Identification System). Sistem distribusi PPDPI saat ini antara lain :
- Sistem Informasi Kenelayanan (SI Kenelayanan/NELPIN atau NelayanPintar)

Sistem ini berdasarkan pada aplikasi android yang dapat di install didalam smartphone yang dapat diunduh gratis pada google store.

- Whatsapp group

Sistem ini memungkinkan distribusi PPDPI melalui group yang anggotanya adalah nelayan dan fihak lain yang berkeptingan.

- AplikasiLaut Nusantara

Aplikasi ini merupakan aplikasi android yang kembangkan oleh BROL bersama PT. XL Axiata.

- Melalui AIS (Camar-BPPT)

Distribusi ini merupakan rancangan pengembangan teknologi yang terbaru kerjasama antara BROL dengan BPPT, dimana informasi PPDPI dimasukkan kedalam perangkat navigasi keselamatan pelayaran AIS tipe B (Gambar.3). Berdasarkan pada gambar.3 dapat dijelaskan bahwa BROL informasi PPDPI diproduksi oleh BROL. Informasi tersebut kemudian disebarluaskan kepada nelayan melalui perangkat AIS. Integrasi antara informasi PPDPI denngan perangkat AIS memberikan keuntungan bagi nelayan sebagai panduan penentuan lokasi potensial penangkapan ikan, sekaligus sebagai fitur keamanan jika terjadi kecelakaan karena posisi kapal dapat dipantau setiap saat. Bisnis proses daripenggunaan AIS ditunjukkan pada gambar. 4. 


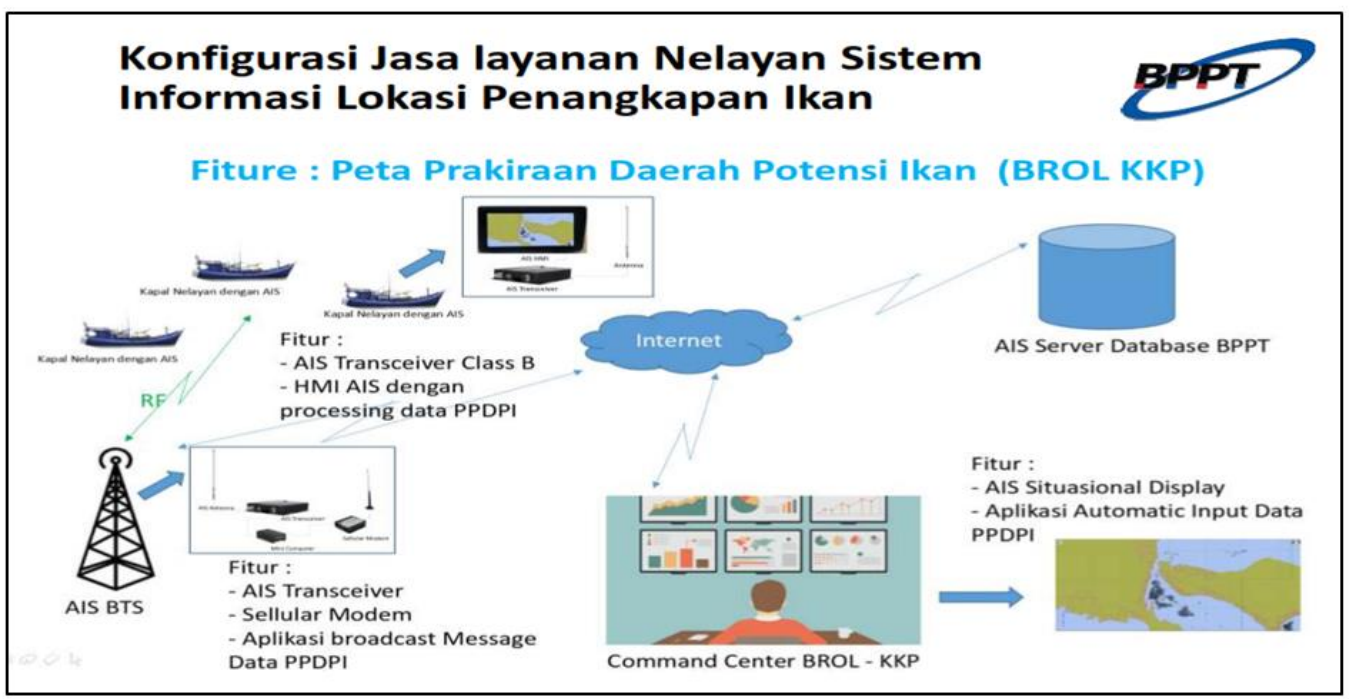

Gambar.3. Design Jasa layanan Nelayan (Courtesy: BPPT)

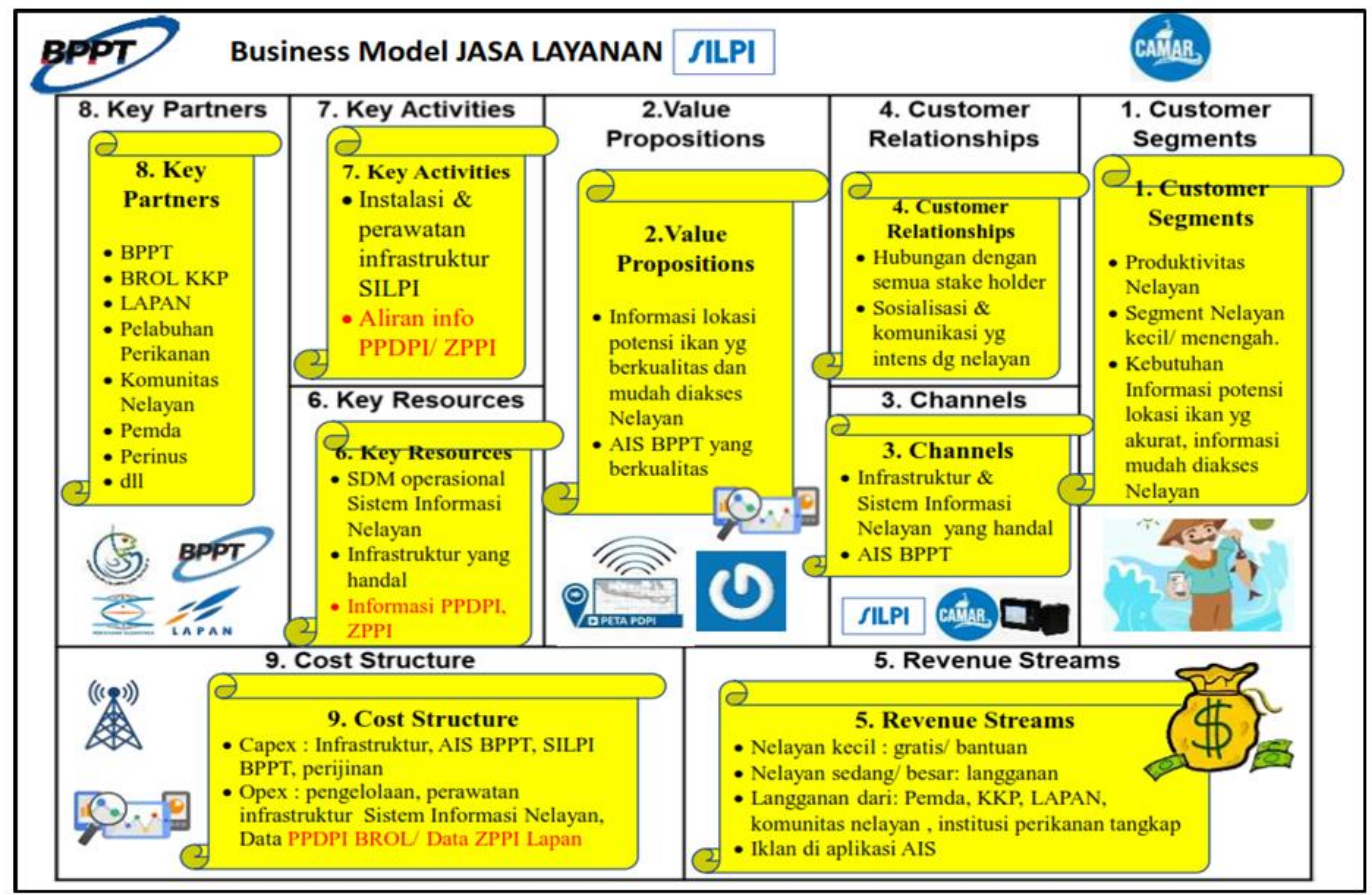

Gambar 4. Business Model Jasa Layanan (Courtesy : PTE BPPT)

\section{KESIMPULAN}

Berdasarkan pada pembahasan diatas dapat ditarik kesimpulan sebagai berikut :

a. Penangkapan yang lestari dengan memperhatikan sumberdaya ikan yang berkelanjutan sangat dibutuhkan. Salah satu cara yang efektif adalah dengan memberikan informasi mengenai daerah penangkapan ikan yang akurat serta memperhatikan kearifan lokal (local wisdom) yaitu PPDPI, sehingga nelayan lebih selektif dalam operasional penangkapan ikan, lebih efisien waktu dan tidak melakukan penangkapan yang merusak lingkungan.

b. PPDPI disusun menggunakan data satelit dengan resolusi spatial dan temporal yang tinggi berdasarkan pada analisis korelasi 
antara kelimpahan ikan di suatu perairan dengan kondisi oseanografisnya.

c. Dengan berbagai jenis PPDPI yang diproduksi maka nelayan sebagai pengguna dapat menyesuaikan dengan daerah penangkapan ikan, ukuran kapal dan jenis alat tangkapa yang digunakan.

d. Akurasi PPDPI yang tinggi memberikan kepastian mengenai hasil penangkapan ikan di daerah yang potensial untuk para nelayan.

e. Proses distribusi PPDPI melalui berbagai media memberikan kemudahan kepada pengguna untuk mendapatkan informasi dimanapun dan kapanpun.

\section{UCAPAN TERIMAKASIH}

Penulis menyampaikan terimakasih kepada National Aeronautics and Space Administration (NASA) atas penyediaan data satelit oseanografi. Terimakasih juga disampaikan kepada European Commission and Mercator Ocean yang telah menyediakan data Copernicus Marine Environment Monitoring Service (CMEMS). Tidak lupa penulis menugcapkan terimakasih kepada Direktorat Sumberdaya Ikan-KKP atas penyediaan data logbook penangkapan ikan di wilayah Indonesia.

\section{DAFTAR PUSTAKA}

[1] R. Dahuri, "Paradigma Baru Pembangunan Indonesia Berbasis Kelautan". Pidato Pengukuhan Guru Besar Fakultas Perikanan dan Ilmu Kelautan, Institut Pertanian Bogor, 2003.

[2] D. Jatisworo dan A. Murdimanto, "Peranan Teknologi Penginderaan Jauh bagi Penangkapan Ikan di Indonesia (Studi Kasus Kabupaten Indramayu)", Bunga Rampai Penginderaan Jauh Indonesia, Pusat Penginderaan Jauh ITB, 2012.

[3] Kementerian Kelautan dan Perikanan, Website ; https://kkp.go.id/kategori/164Peta-Prakiraan-Daerah-PenangkapanIkan di download pada 5 Maret 2021.

[4] Departemen Kelautan dan Perikanan, Rencana strategis pembangunan kelautan dan perikanan 2001 - 2004. Departemen Kelautan dan Perikanan, Jakarta, 2002.

[5] B. Sukresno, A. Hartoko dan B. Sulistyo, "Empirical cumulative distribution function (ECDF) analysis of Thunnus. sp using ARGO Float sub-surface multilayer temperature data in Indian Ocean South of Java". Procedia Environmental Sciences, Vol. 23, Hal. 358-367, 2015.

[6] E. Susilo, T. A. Wibawa, dan A. Wijaya, "Pendugaan Daerah Penangkapan Ikan Lemuru Di Selat Bali Berbasis Rantai Makanan Menggunakan Data Satelit Osenografi",. Balai Penelitian dan Observasi Laut-KKP, 2015.

[7] Departemen Kelautan dan Perikanan, "Pemanfaatan dan pengembangan Peta Prakiraan Daerah Penangkapan Ikan (PPDPI)", Laporan kegiatan Pusat Riset Teknologi Kelautan, Badan Riset Kelautan dan Perikanan, DKP, 2003.

[8] B. Hasyim dan N. Salma, "Analisis Distribusi Suhu Permukaan Laut dan Kaitannya Dengan Lokasi Penangkapan Ikan dan Laju Pancing Ikan Tuna di Perairan Selatan Bali", Prosiding Pertemuan Ilmiah Tahunan ke 8 MAPIN, Jakarta, 1998.

[9] A.F.G. Fiuza, "The Measurement of Sea Surface Temperature From Satellite", Hal. 197 - 280. dalam A.P. Cracknell, "Space Oceanography", World Scientific Publishing Co. Pte. Ltd. Singapura, 1992.

[10] D. Jatisworo dan A. Murdimanto, "Identifikasi thermal front di Selat Makassar dan Laut Banda", Simposium Nasional Sains Geoinformasi III, University Club, Universitas Gadjah Mada, Yogyakarta, Hal. 25-26, 2013.

[11] R. Hanintyo, S. Hadianti, R.P. Mahardhika, J. Aldino dan F. Islamy, "Sebaran Musiman Kejadian Thermal front Berdasarkan Citra Aqua-MODIS di WPP-RI 714, 715, WPP-RI 716”. Prosiding Seminar Nasional Penginderaan Jauh Nasional, 2015.

[12] W. E. Rintaka, E. Susilo dan A. W. Hastuti, "Pengaruh In-Direct Upwelling Terhadap Jumlah Tangkapan Lemuru Di Perairan 
Selat Bali”, Seminar Nasional Perikanan dan Kelautan $V$ Universitas Brawijaya, Hal. 312-319, 2015.

[13] B. Sukresno, D. Jatisworo dan D.W. Kusuma, "Analisis multilayer variabilitas upwelling di perairan Selatan Jawa", Jurnal Kelautan Nasional, Vol. 13, No. 1, 15, 2018.

[14] R. Hanintyo, "Spatio-Temporal Habitat Suitability Detection for Small Pelagic Fish Using Earth Observation Data on Nusa Penida Coast Bali, Indonesia" Master's thesis, University of Twente, 2019.

[15] K. I. Suniada, E. Susilo dan A. W. Hastuti, "Validasi Peta Prakiraan Daerah Penangkapan Ikan (PPDPI) di Perairan Laut Jawa (WPP-RI 712)", Prosiding Forum Nasional Sains dan Teknologi Kelautan dan Perikanan, 2015.

[16] W.E. Rintaka dan E. Susilo, "Validation of potential fishing zone forecast using experimental fishing method in Tolo Bay, Central Sulawesi Province". IOP Conference Series: Earth and Environmental Science, Vol. 137, No. 1, Hal. 012-041, 2018.

[17] N. M. Farda dan D. Jatisworo, "Penambangan Pola Ruang Waktu Pada Peta Prakiraan Daerah Penangkapan Ikan Di Perairan Wilayah Pengelolaan Perikanan (WPP) 712, 713, DAN 573", Majalah Ilmiah Globe, Vol. 21, no. 2, Hal. 117-128, 2019.

[18] B. Sukresno, A. Murdimanto, R. Hanintyo, D. Jatisworo dan D.W. Kusuma, "The use of CMEMS and Argo float data for bigeye tuna fishing ground prediction", IOP Conference Series: Earth and Environmental Science, Vol. 246, No. 1, 2019.

[19] D. Jatisworo, A. Murdimanto, D.W. Kusuma, . Sukresno, dan . Berlianty, "Analisis Penerapan Metode Gap Filling Untuk Optimalisasi Perolehan Data Suhu Permukaan Laut Bebas Awan Di Selat Bali", Jurnal Penginderaan Jauh dan Pengolahan Data Citra Digital, Vol. 15, No. 2, 2019.
[20] K. I. Suniada, E. Susilo, W. E. Rintaka dan N. Widagti, "Rolling Mosaic Method To Support The Development Of Potential Fishing Zone Forecasting For Coastal Areas", International Journal of Remote Sensing and Earth Sciences (IJReSES), Vol. 16, No. 2 Hal. 107-120, 2020.

[21] D.W. Kusuma, A. Murdimanto, B. Sukresno dan D. Jatisworo, "Comparison of interpolation methods for sea surface temperature data", Journal of Fisheries and Marine Research, Vol. 2, No. 2, Hal. 103-115, 2018.

[22] B. Sukresno, R. Hanintyo, D. W. Kusuma, D. Jatisworo dan A. Murdimanto, "Threeway error analysis of sea surface temperature (SST) between HIMAWARI8, buoy, and mur SST in SAVU Sea", International Journal of Remote Sensing and Earth Sciences (IJReSES), Vol 15, No. 1, Hal. 25-36, 2018 a. 